\title{
バイオインフォマティクスとケモインフォマティクスの融合による インシリコ創薬研究
}

\author{
奥 野恭史
}

\section{In silico Drug Discovery Based on the Integration of Bioinformatics and Chemoinformatics}

\author{
Yasushi OKUNO \\ Department of PharmacoInformatics, Centre for Integrative Education of Pharmacy Frontier, \\ Graduate School of Pharmaceutical Sciences, Kyoto University, 46-29 Yoshida \\ Shimoadachi-cho, Sakyo-ku, Kyoto 606-8501, Japan
}

(Received May 28, 2008)

\begin{abstract}
With the near completion of the human genome sequencing, bioinformatics and chemoinformatics are expected as promising tools in genome-based drug discovery. The emerging field of chemical genomics is accumulating large-scale assay data on compound-protein interactions. We are now developing new mining methods for the chemical genomics data based on the integration of bioinformatics and chemoinformatics. Here we present a GPCR-ligand database (GLIDA) and a novel in silico screening method, which we have developed. GLIDA is a novel public GPCR-related chemical genomics database that is primarily focused on the correlation of information between GPCRs and their ligands. Our in silico screening method is based on statistical machine learning of the conserved patterns of molecular recognition extracted from comprehensive compound-protein interaction data. These are promising approaches to accelerating drug discovery processes.
\end{abstract}

Key words_ chemoinformatics; bioinformatics; in silico screening

\section{1.はじめに}

ヒトゲノムが解読された今日，莫大なゲノム情報 から創薬への手掛かりを発見すること，すなわち 「ゲノム創薬」に大きな期待が寄せられている。ゲ ノム創薬は，ゲノム情報を出発点とし創薬の標的遺 伝子探索からリード化合物探索を経て臨床段階に至 る広範で高度に専門化した複合領域であり，その実 践にはこれらの複合領域の橋渡しを実現する統合的 なインフォマティクス基盤「創薬インフォマティク ス」が必須となる，われわれは，創薬インフォマテ イクスという新たな研究分野の創成に向け，バイオ 情報を扱うバイオインフォマティクスとケミカル情 報を扱うケモインフォマティクスという独立に発展 してきた 2 つの情報科学分野の統合を図り，バイオ

京都大学大学院薬学研究科統合薬学フロンティア教育 センター（干606-8501 京都市左京区吉田下阿達町 4629)

e-mail: okuno@pharm.kyoto-u.ac.jp

本総説は, 平成 20 年度日本薬学会奨励賞の受賞を記念

して記述したものである。
情報とケミカル情報の両者を同時に統合的にマイニ ングする新しい情報技術の開発に着手している．な お本研究は, 現在, 国内外で注目されているケミカ ルゲノミクス・ケミカルバイオロジーのための有力 な情報基盤ともなり得るものと考えられる.

2. ケミカル空間とケミカルゲノミクス

2004 年 12 月の Nature 誌において, Chemical Space 特集号が発表された. ${ }^{1)}$ そこでは，化合物の 種類は $10^{60}$ 個を超える天文学的なバリエーション を有しており，化合物空間を探索することは宇宙探 索と同様に壮大な課題であることが提示されてい る.このことは医薬品の候補化合物となり得る新規 な活性化合物を見つけ出すことがいかに困難でセレ ンディップなことであるかを示唆するものである.

これらケミカル空間の探索の基礎研究としてケミ カルゲノミクス・ケミカルバイオロジー研究が近年 注目されている。ケミカルゲノミクスでは，その命 題として「莫大な数の化合物と生体系（タンパク質 や細胞など）との相互作用を包括的に明らかにする 
こと」が挙げられている。実際，米国では，ケミカ ルゲノミクスプロジェクトを掲げ，数百万もの膨大 な化合物に関する情報を収集し，有用化合物の探索 に国策として取り組んでいる.

しかしながら，広大な化合物空間から生物活性を 有する化合物を探し当てる化合物探索には，天文学 的な数量に対応できる新たなインフォマティクス技 術とハイスループット技術の研究開発が必須であ る。そこで，われわれは，莫大な化合物群とタンパ ク質群との相互作用様式をゲノムスケールで解析す ることを目的とした情報学的技術，すなわちケミカ ルゲノミクスのためのインフォマティクス技術の研 究開発を行っている.

\section{3. ケモインフォマティクスとバイオインフォマ} ティクス

ケミカルゲノミクス・ケミカルバイオロジーで は，化合物のケミカル情報と生体系のバイオ情報の 2 種の異なる情報が対象となる。したがって，ケミ カルゲノミクスのための情報処理技術には，ケミカ ル情報を処理するケモインフォマティクスとバイオ 情報を処理するバイオインフォマティクスを融合す る新たなインフォマティクス技術の開発が必須とな る. しかしながら，化学と生物学という異なる分野 を背景に持つ 2 つのインォマティクスは，独立し て発展してきており現状では互いに相容れない。そ こで，われわれはケモインフォマティクスとバイオ インフォマティクスにおける方法論的なアナロジー に着目しその融合を図った。すなわち，ケモインフ オマティクスもバイオインフォマティクスもとも に，個体（化合物やタンパク質）の特徵量を数值や ベクトルで表現することにより，各個体の相対的な 特性の違いを探索空間上の個体間の距離として定量 的に算出する方法論を基本としている．例えば，ケ モインフォマティクスでは，データベースに集積さ れた膨大な化合物エントリーは化学構造や特性を定 量的に表すべクトルとして表現され，その相対的な 違いを距離の尺度として持つ座標空間（探索空間） をコンピュータ内部に構築する。データベース検索 はこの探索空間において距離が近接する化合物を類 似化合物として選出してくることになる．また，バ イオインフォマティクスでも同様の考え方であり, 遺伝子・タンパク質エントリーは配列や構造として 表現され，それぞれの相同性（類似度）を尺度とし
て持つ探索空間（バイオデータの場合，探索空間は 系統樹やネットワーク構造になっている場合もあ る）が構築され，データベース検索にはこの探索空 間に基づき，類似（類縁）遺伝子・タンパク質が選 出される.

一方，ケミカルゲノミクスとは，ケミカル空間の 個体（化合物）とバイオ空間の個体（遺伝子・タン パク質）との相互作用関係を網羅的に明らかにする 研究であり，Fig. 1 の赤線に示す対応関係を付加し たモデルであると考えられる。ここで，われわれ は，ケミカル情報とバイオ情報を統合的に処理する ために，ケミカル空間（緑色）とバイオ空間（黄色） を独立して扱うのではなく，2つの空間を融合した モデルをケミカルゲノミクスのためのインフォマテ ィクスモデルとして考案した.

\section{4. ケミカル空間とバイオ空間の融合モデル}

情報科学的アプローチによる化合物探索は，これ まで化合物のケミカル情報のみを用いたケモインフ オマティクス手法が用いてきた。これに対し，われ われの手法は，このケミカル情報のみの従来手法に バイオインフォマティクス技術を融合させ，バイオ 情報を考慮に入れた化合物探索を実現する新しいイ ンフォマティクス手法と言える（Fig. 1).

例えば，化合物について構造や特性の類似性を相 対的な位置関係として表現したものをケミカル空間 （赤が化合物，緑領域がケミカル空間）として定義 するとともに，タンパク質についても類似関係（配 列や構造の相同性）を相対的な位置関係として表現 したものをバイオ空間（青がタンパク質，黄色領域 がバイオ空間）として定義する。ささらに個々の化合 物とタンパク質の結合をリンク（黒線）することに よって，これらケミカル空間とバイオ空間を融合し た単純なモデルを構築できる（Fig. 2).

ここで，標的タンパク質に作用する化合物候補を 探索するIn silico スクリーニングにこの融合モデ ルを適用する場合を考えると，

1）標的タンパク質（青星）の配列構造から，そ のタンパク質がバイオ空間座標にマッピングされる.

2）バイオ空間にマッピングされた標的タンパク 質の近隣タンパク質からのケミカル空間へのリンク 情報をたどること（青矢印）により，その標的夕ン パク質が関係するケミカル空間のエリア（青円内） を指定することができる. 




Fig. 1. Bioinformatics and Chemoinformatics

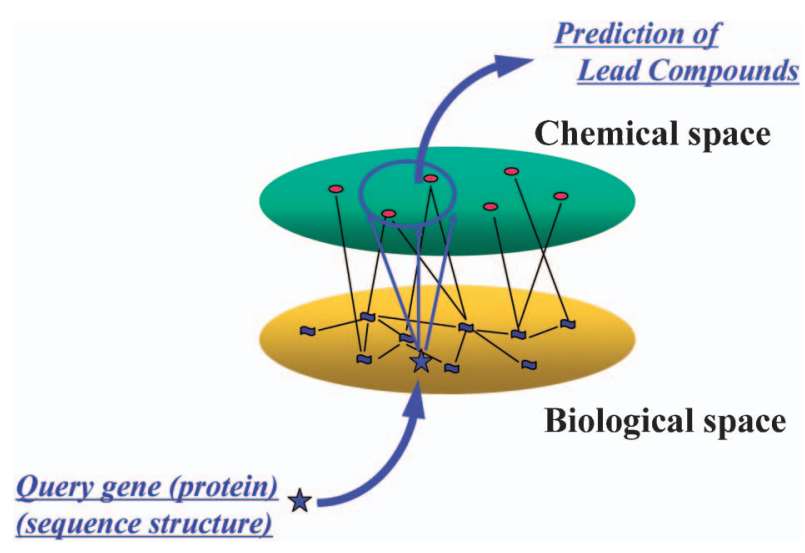

Fig. 2. In silico Screening for Chemical Genomics Data

3）上記エリア内の化合物群が，標的タンパク質 に相互作用する可能性のある化合物群と推定される (ここでは，類似のタンパク質は，類似の化合物を 結合するという前提を基にしている)。

われわれは，このケミカル空間とバイオ空間の融 合モデルを用いた探索を，GPCR ファミリーとそ のリガンド化合物の探索に適用し，GLIDA データ ベース ${ }^{2-4)}$ として Web サービスを行っている，GLIDA は，GPCR のバイオ情報，そのリガンドのケミ カル情報, 及び GPCR とリガンドの相互作用情報 の 3 種類の情報より構成されている. GPCR の工 ントリーはヒト, ラット，マウスに限定し，バイオ 情報は GPCRDB から取得した。また，GPCR と結 合するリガンドのエントリーとそのケミカルデータ (化学名, 構造式, 分子量, MDL Mol ファイルな ぞ）は IUPHAR Receptor Database, PubMed, Pub-
Chem 及び MDL ISIS/Base 2.5 などの公共又は商 用のデータベースから取得した。具体的には，2008 年 1 月現在, 24077 件のリガンドエントリー, 及び 39140 件のリガンド-GPCR の相互作用エントリー の登録に至っている.

各エントリーの検索は, GPCR (またはリガンド) のキーワード検索及びクラス分類テーブルから行う ことが可能である。ここで, GPCR 分類は, GPCRDB に定義されている進化系統樹由来の分類 に従っている。 またリガンド分類は，KEGG で定 義されている原子タイプの原子数／結合数に基づい た頻度プロファイルから距離行列を計算し，主成分 分析（PCA）に基づいて GLIDA 独自のリガンド 分類を行っている，検索された各 GPCR（または リガンド）のページには，バイオ情報（またはケミ カル情報），及びそれらに結合するリガンド（また は GPCR）のリストが同時に表示される.さらに， GLIDA の GPCR（またはリガンド）のページは GPCR-リガンド相互作用の解析機能を有してい る。すなわち，検索された GPCR（またはリガン ド）と最も高い類似性を持つ 25 個の GPCR（また はリガンド）リストを表示するとともに，これら 25 個のエントリーと結合するリガンド（または GPCR）との相互作用様式を 2 次元マップ表示す る.このマップの 2 軸に並ぶ GPCR とリガンドの 順番は, 各々 GPCR とリガンドのクラスタリング 結果を反映している。したがって, GPCR, リガン ドの類似性情報と相互作用情報を同時に視覚化し， このパターンを分析して GPCR とリガンドの相互 
作用予測を実現し，薬物と作用基点の相互作用に関 する情報を得ることができる（Fig. 3, Fig. 4）。

5. ケミカルゲノミクスに基づくバーチャルスク リーニング

活性化合物を効率よく迅速に探し出すために，計 算機を用いた候補化合物の絞り込み手法「バーチャ ルスクリーニング（VS）」が開発されてきた. 現在 よく用いられているVS として，既知リガンドとの 構造類似性に基づく「Ligand-based virtual screening (LBVS)」と標的タンパク質の立体構造に基づ $<\lceil$ Structure-based virtual screening (SBVS) 」が ある. ${ }^{5,6)}$ この 2 つの手法は, 近年の情報技術の進歩 と相まって，この 10-20 年で著しい発展を遂げ，ゆ るぎない地位を確立した。しかしながら現在，VS のヒット確率は 1-10\%もあればよしとされており （例えば，LBVS では，既知活性化合物の骨格構造 に強く影響される嫌いがあるし，SBVS では，パラ メータの恣意性，予測的中率の低さなどが指摘され ている)，さらなる技術的な改良や革新的技術の開 発が切望されていることは間違いない.

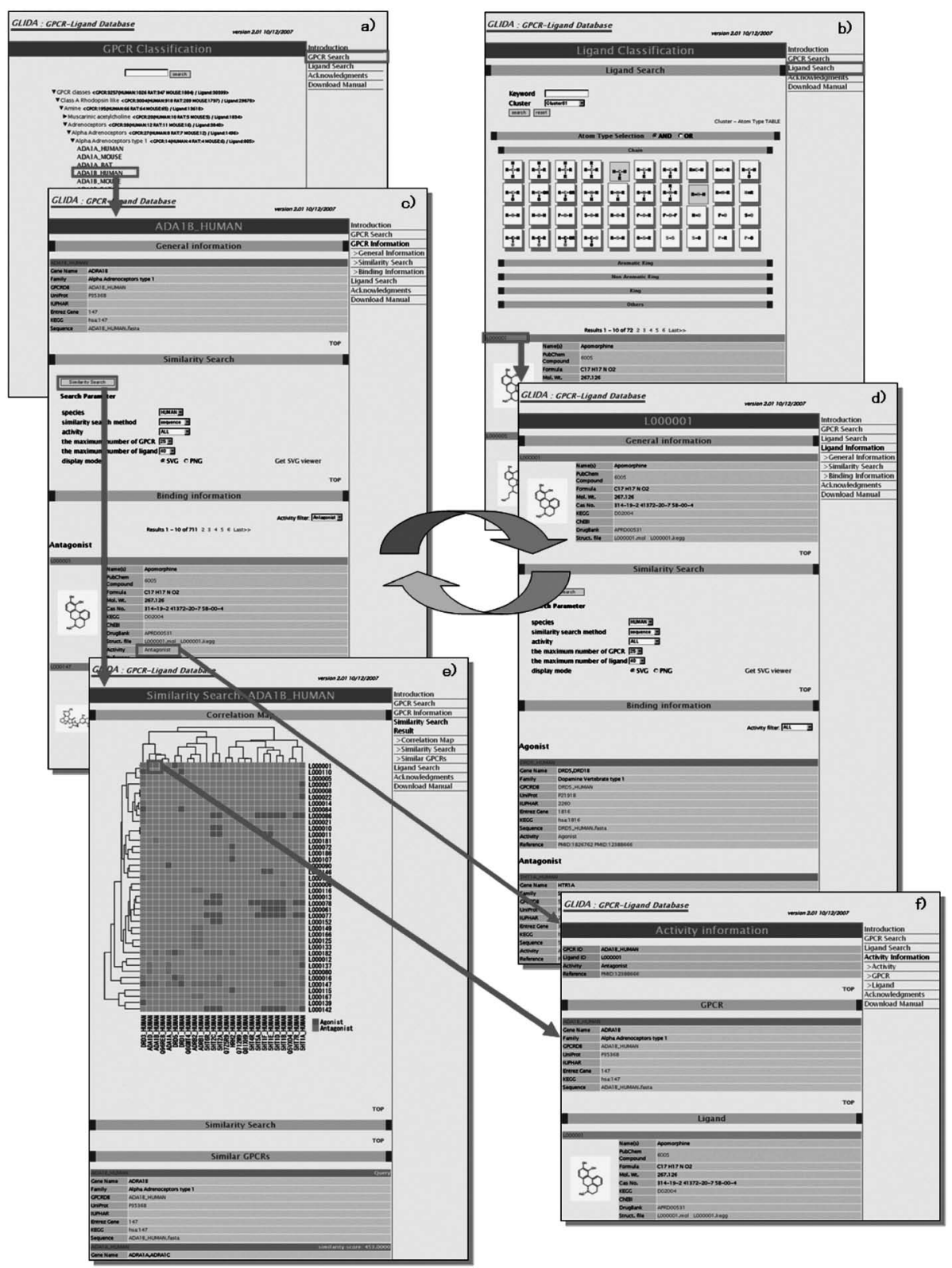

Fig. 3. A Screenshot of GLIDA Showing Linked Relations among Search Pages (a, b), Result Pages (c, d), an Analytical Report Page (e), and a Binding Information Page (f) 


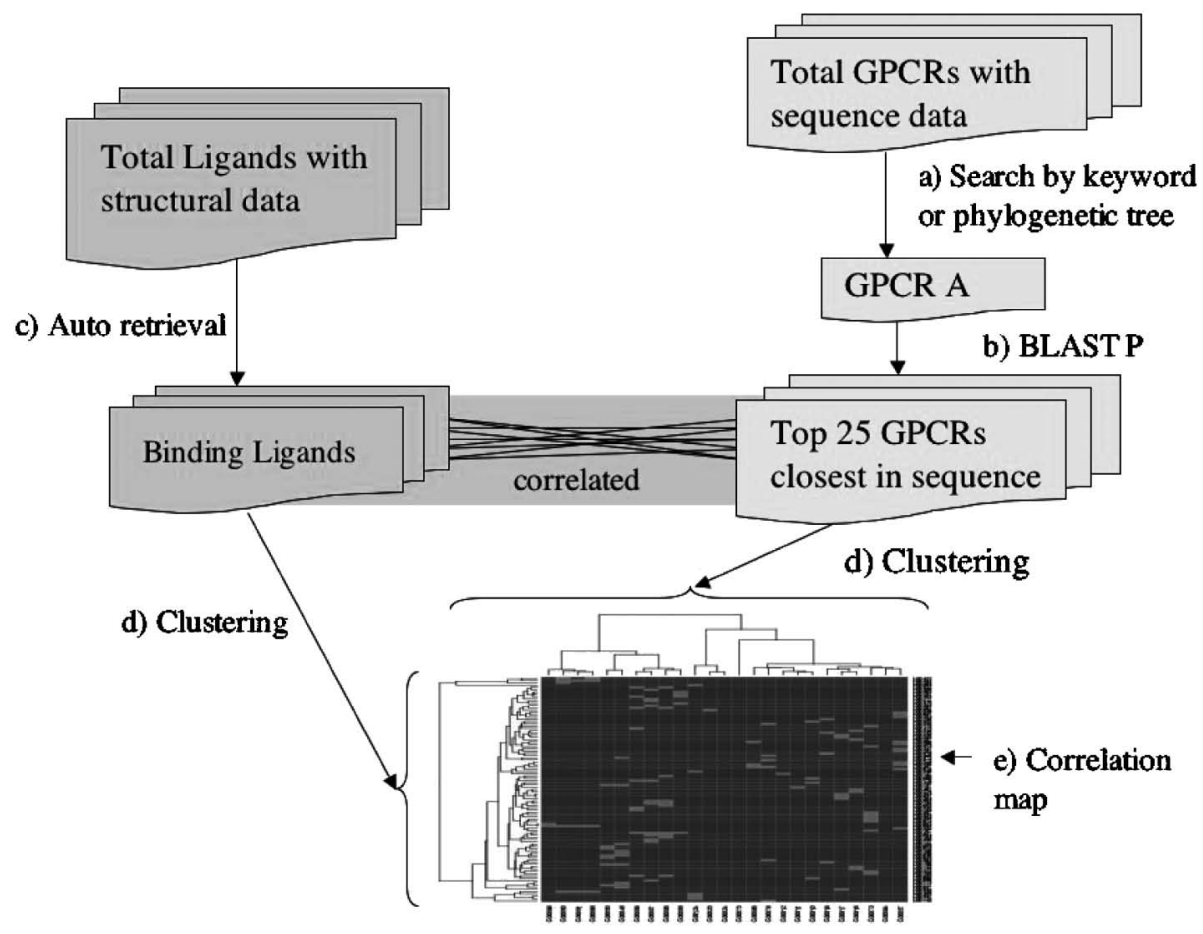

Fig. 4. A Schematic Example of the Search and Analysis Process Showing GPCR-ligand Correlations Produced from a GPCR Query Using GLIDA

ここでは，LBVS やSBVS とは概念の異なる第 3 の VSとして，われわれが開発している「ケミカル ゲノミクスに基づくVS 手法（Chemical Genomicsbased virtual screening; CGBVS)」を紹介する。「ケ ミカルゲノミクス」は，興味を持つ化合物が生物に 与える影響についてゲノム規模で研究する学問であ り ${ }^{7,8)}$ マイクロアレイやハイスループットスクリー ニングなどの同時大量解析技術の革新に後押しさ れ，近年，注目を浴び始めている。それに伴い，化 合物と遺伝子の関連性について，膨大な実験データ が蓄積されている。そこでわれわれは，情報科学技 術の 1 つであるパターン認識技術を用いて，タンパ ク質と化合物との結合情報（ケミカルゲノミクス情 報）から抽出したタンパク質のリガンド認識パター ンに基づいて活性化合物を効率的に発見する新たな VS，「CGBVS」を開発している.

タンパク質とリガンドとの相互作用パターンの認 識とそのリガンド予測を開発するために，われわれ は学習アルゴリズムの一種であるサポートベクター マシン $(\mathrm{SVM})^{9)}$ を用いた. SVM は，2 クラス分類

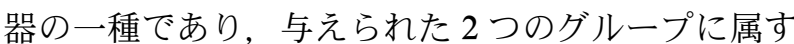
る特徵ベクトルを最大マージンで分離するような超 平面を構築する。ここで，最大マージンとは，分離
した超平面から各サンプル間までの最短距離を指す。

われわれは，この SVM を用いて，化合物ータン パク質相互作用の有／無を判別する手法を開発し た。その手法の流れを Fig. 5 に示す。まず，収集 した相互作用をべクトルとして表現するために，各 化合物の化学構造，各タンパク質のアミノ酸配列に ついて，様々な属性（記述子と呼ぶ）を計算する. 次に，正例（相互作用する化合物ータンパク質ペア） 及び負例（相互作用しない化合物ータンパク質ペア） に対応する記述子をそれぞれ組み合わせて特徵べク トルを構成し，SVM を用いて学習モデルを構築す る.このモデルが得られると，（未知の化合物ータン パク質ペアに相当する）新しいベクトルが相互作用 有／無のどちらのクラスに属するかを予測するこ とができる。

既存のVS 手法との比較検討を行うため, 今回開 発した CGBVSとLBVSとの予測性能を比較し た. 収集した化合物-GPCR 相互作用を用いて，負 例を交換しながら 5 分割交差検定法（5 fold crossvalidation）を試行した。交差検定の結果，最近傍 法を用いた LBVS では $84.4 \pm 0.3 \%$, CGBVS では $91.6 \pm 0.2 \%$ の相互作用を正しく予測した。また， ROC 曲線からも，CGBVS の予測性能の高さが確 


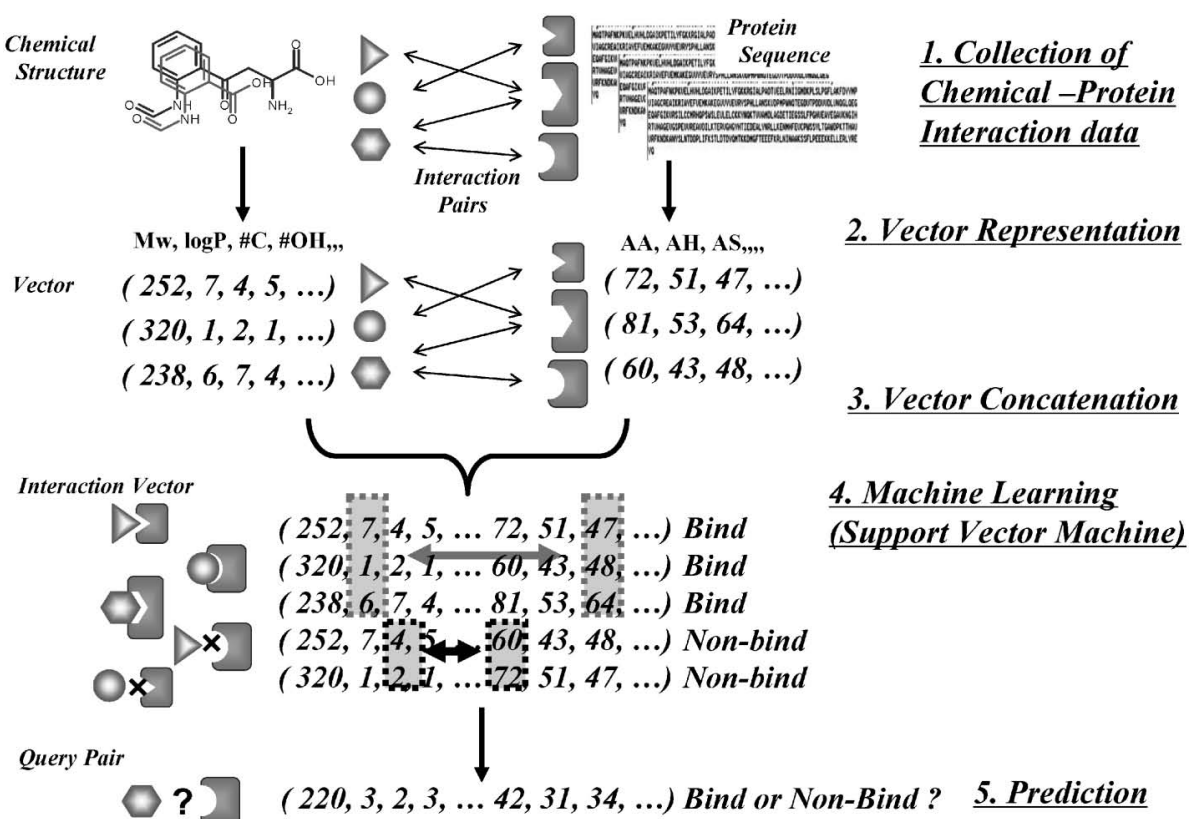

Fig. 5. Overview of Chemical Genomics-based Virtual Screening

認された（Fig. 6). したがって，ケミカルゲノミ クス情報の活用がリガンド予測性能の向上につなが つたといえる.

さらに，ヒト $\beta 2$ アドレナリン受容体（ $\beta 2 \mathrm{AR} ）$ を標的 GPCR とし，構築した学習モデルを用いて リガンド予測を行い, in vitro 実験による検証を行 つた。リガンド予測の対象化合物は， $\beta 2 \mathrm{AR}$ 以外の GPCR のリガンドとして知られている 826 化合物 とした。ここで，CGBVSにより予測された $\beta 2 \mathrm{AR}$ リガンド候補上位 50 の化合物のうち, 文献・特許 調査により 14 種の化合物について $\beta 2 \mathrm{AR}$ との相互 作用に関する報告を確認した。さらに，残りの相互 作用不明な化合物のうち，入手可能な 21 種類につ いて in vitro 結合阻害実験を行ったところ，17 種類 の化合物が相互作用 $\left(10^{-5} \mathrm{M}<\mathrm{IC}_{50}<10^{-3} \mathrm{M}\right)$ を示 した。結合阻害実験のヒット率は 81\% (17/21) に 上り，ここにおいても高い予測的中率が示された.

また今回新たに発見した化合物の化学構造を精査し たところ，典型的な $\beta 2 \mathrm{AR}$ 作動薬の構造（カテコ ラミン骨格，イソプレナリン誘導体）及び $\beta 2 A R$ 拮抗薬の構造（アリルアルキルアミン誘導体）とは 異なる多様な骨格を含んでおり，化合物の構造類似 性に基づく従来の方法では発見が困難なリガンド群 が含まれることが明らかになった。したがって，ケ ミカルゲノミクス情報が，リガンド予測精度の向上

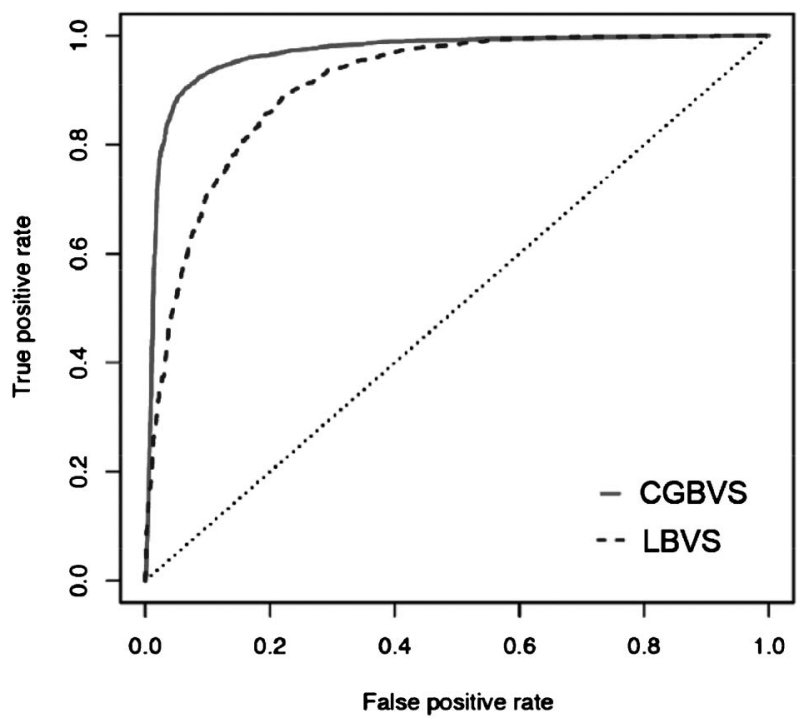

Fig. 6. Comparison of Prediction Performance between Chemical Genomics-based and Ligand-based Virtual Screenings

のみならず，新規骨格を持つリガンドの検出にも有 用であることが示唆された。

\section{6. おわりに}

従来，生物活性を示す化合物の探索には，化合物 の構造類似性がその指標とされてきた. しかし，化 合物の構造類似性だけでタンパク質との多種多様な 相互作用を見い出すには限界があり, 新しい探索手 法の開発が望まれていた。われわれは，「ケミカル 
ゲノミクス情報の中から相互作用パターンを抽出す る」という新しいアプローチを試み，1）化合物GPCR 質間相互作用データベース GLIDA を開発 し，2）学習アルゴリズムを用いた予測モデルによ り，GPCR リガンドを精度よく予測できることを 実証した。

なお， $\beta 2 \mathrm{AR}$ の立体構造が 2007 年決定された ${ }^{10)}$ ことを受けて，われわれはSBVS との予測性能比 較も行っており，その結果，CGBVSがSBVSより も高精度で $\beta 2 \mathrm{AR}$ リガンドを予測できることを確 認している。

われわれが開発している CGBVS は，標的タンパ ク質のリガンド情報がないケースにも適用可能であ り，実際に現在，オーファン GPCR を標的とした リガンド予測を行っている. タンパク質の立体構造 情報を必要としない点は，詳細な 3D 構造が不明な GPCR にとって，魅力的なリガンド予測手法とい える，将来的には，結合阻害定数（Ki 值）など定 量的な活性データから回帰分析を行うことにより, 相互作用の強さを反映させたリガンド予測手法への 拡張を行う予定である。ケミカルゲノミクス情報を 利用するという新規なアプローチは，GPCR に限 らずすべてのタンパク質に適用可能であり，化合物一 タンパク質相互作用の理解，ひいては創薬プロセス の効率化につながることが期待される。

謝辞本研究の一部は, 文部科学省, 経済産業 省（NEDO 若手グラント），厚生労働省の助成金支 援によって行われており，深く感謝申し上げる，本 総説は，平成 20 年度日本薬学会奨励賞の受賞を記 念して記述したものであり, 日本薬学会役員, 審査
員の先生方をはじめご関係の皆様に心より感謝申し 上げる。また，これまでご指導，ご鞭撻賜りました 学生時代の恩師・杉浦幸雄先生（現同志社女子大学 教授），研究員時代の恩師・金久 實先生（京都大 学化学研究所教授), 助手時代の恩師・辻本豪三先 生 (京都大学薬学研究科教授), 並びに京都大学薬 学研究科研究科長・藤井信孝先生に謹んで感謝の意 を表します。

\section{REFERENCES}

1) Nature, 432 (7019) (Insight), 823-865 (2004).

2) Okuno Y., Yang J., Taneishi K., Yabuuchi H., Tsujimoto G., Nucleic Acids Res., 34, D673-677 (2006).

3) Okuno Y., Tamon A., Yabuuchi H., Niijima S., Minowa Y., Tonomura K., Kunimoto R., Feng C., Nucleic Acids Res., 36, D907-D912 (2008).

4) 〈http://pharminfo.pharm.kyoto-u.ac.jp/services/glida/>

5) Muegge I., Oloff S., Drug Discov. Today Technol., 3, 405-411 (2006).

6) Oprea T. I., Matter H., Curr. Opin. Chem. Biol., 8, 49-58 (2004).

7) MacBeath G., Genome Biol., 2, COMMENT2005 (2001).

8) Salemme F. R., Pharmacogenomics., 3, 257267 (2003).

9) Vapnik V. N., "The Nature of Statistical Learning Theory," Springer, New York, 1995.

10) Cerezov V., Science., 318, 1258-1265 (2007). 